Original Article

Received/Accepted Dates

07.12.2021/20.02.2021

DOI 10.52096/usbd.6.24.6
International Journal of Social Sciences

Uluslararası Sosyal Bilimler Dergisi

www.sobider.net ISSN: 2548-0685

\title{
Çağdaş Kültürel ve Sosyal Yapıda Sanat Olarak Dövmelerin İncelenmesi' ${ }^{1}$
}

\author{
Arefa SARAMi \\ Dinler ve Medeniyetler Fakültesi \\ İsfahan Güzel Sanatlar Üniversitesi \\ Çev: Dr. Muhammet Fatih DEMİRDAĞ \\ Hakkâri Üniversitesi İlahiyat Fakültesi \\ mfatihdemirdag@hakkari.edu.tr \\ Çev: Dr. Nasrin ZABETI MIANDOAB \\ İran İslam Cumhuriyeti Allame Tabatabayi Üniversitesi \\ nasrin.zabeti@gmail.com
}

\section{Özet}

Gerek günümüzde gerekse geçmiş dönemde insanların ortak kültürel ve sosyal eylemlerinden biri de beden üzerinde resim yaratmaktır. Bu farklı sosyal davranış türlerine tattoo, dövme ve vücut boyama (vücut üzerinde resim çizme) denilmektedir. Beden üzerinde estetik bir bakış açısıyla kalıp oluşturmanın (resimler yaratmanın) bir sanat olduğunu kabul edersek, o zaman sanatın antropolojik yaklaşımıyla her toplumun kültürel ve çevresel yapısı o toplumun baskıları ve sınırlamaları dikkate alınarak incelenebilir.

$\mathrm{Bu}$ araştırmada, kendi çağdaş toplumda dövmeye daha açık bir bakış açısı yaratmak için Franz Boas'ın sanat antropolojisindeki estetik özelliklerinden yararlanarak sanatçının ve bu sanatın izleyicisinin bakış açısıyla anlam aramaya çalışmıştır. Bu sanat ve meslekteki ortak küresel özellikleri göz önünde bulundurarak, özel üslup özelliklerinin yaratılmasına neden olan özel kültürel ve sosyal yapısı incelenmiştir. Bu çalışmanın amacı, sanat antropolojisi alanında dövmelerle ilgili iki noktayı incelemektir; ilki, dövmelerle ilgili sanat teorilerinde bulunan olağan estetik özelliklerin ne ölçüde olduğudur? Ardından dövmelerin sadece estetik özellikleri değil aynı zamanda özel, kültürel ve sosyal aidiyetleri olduğunu da

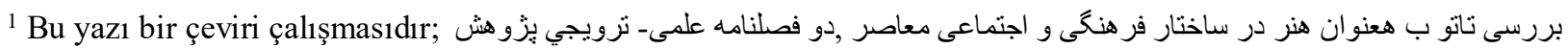

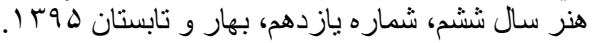


göz önünde bulundurarak dövmelerin çağdaş kültürel ve sosyal yapıdaki işlevlerinin incelenmesidir. Bu çalışmaya göre dövme tasarımları ve vücut üzerinde yaratılmaları, İran gibi bir toplumun kültürel ve sosyal yapısında estetik değere ve dekoratif özelliklere sahipken, güzellik arzusu ve daha da önemlisi bireysel arzulardan türetilebilir. Grup ve ritüel eğilimleri gibi sosyal ilişkilerden ve o toplumun kendine özgü kültürel ve tarihsel bağlamından etkilenen sembolik bir anlamı vardır.

Anahtar Sözcükler: Dövme, sanat antropolojisi, estetik özellikler, sembolik anlam, kültürel ve tarihsel bağlam.

\title{
An Investigation of "Tattoo" as an Art in the Contemporary Culture and Society
}

\begin{abstract}
Body painting has been practiced in the wide variety of cultures which includes Tattooing, Marking, and Ink Painting. In this study, we have explored whether tattoos should be counted as art and if they should, their aesthetic characteristics have been extracted based on the Franz Boas analytical method in anthropology of art. In this study, we attempted to investigate two issues about tattooing: 1) How the common aesthetic characteristics in art theories could be understood in tattoo as an artwork, And 2) According to the fact that, in addition to the aesthetic features, tattoo is also associated with social and cultural dependencies, we sociologically attempted to look for the tattoo's functions in the contemporary social and cultural structures. Furthermore, considering the similar features of tattooing art in the world, the cultural style of this art has been studied in our society. According to the observations in this study, tattoo not only has aesthetic value in a cultural context, but also has symbolic meaning which influences and is influenced by individual and social leaning.
\end{abstract}

Keywords: Tattooing/ Marking, Anthropology of art, Aesthetic value, Symbolic meaning, Historical and cultural context.

\section{Giriş}

Yemekten, uyumaktan, dövme yapmaya ve cildi delmeye kadar tüm insan davranışları toplumda insan bedeni aracılığıyla bir anlam kazanmaktadır. Böyle bir insanın algılanabilir bir bedene ve duyulara sahip olduğunu varsaymadan bir insandan bahsetmek mümkün değildir. Merleau-Ponty’a göre "beden, dünyayı algılamak için evrensel bir araçtır". 
Beden, insanın dünyayla ilişkisini anlamasını mümkün kılan bir eksen olarak düşünülmelidir. Bedenin dünya ile her zaman sahip olduğu yakın ilişki, insanın dünyada yolunu açıp, dünyayı ona açık hale getirmektedir (Lubroton, 2014: 8). İnsanın varlığı dünyaya açıktır. İnsan, yaşamın özünü beden aracıllğ̆ıla edinir ve bu özü, bu değerleri anlayan başkalarıyla ortak sembolik değerleri aracıllğıyla ifade eder.

Bedenin sosyal ve kültürel olarak işaretlenmesi, toplumun doğrudan deriye yazılmasıyla yapılabilir. Bu, soyularak, yaralanarak, deforme edilerek veya cilde bir şey eklenerek yapılabilir. Sembolik şekillendirme nispeten şöyledir (Sembolik şekillendirme, insan toplumlarında nispeten yaygın bir eylemdir.): Vücudun ritüel olarak kesilmesi, ciltte derin işaretleme, kalıcı veya geçici dövmeler, makyaj vb. şeklinde cilt yazımı, vücudun genel deformasyonları (kafatası çizimi, deforme olmuş bacaklar) (Parry, 2006: 6-8).

Vücuda uygulanan kalıcı veya geçici değişiklikler ${ }^{2}$ tıbbi ve tıbbi olmayan nedenlerle meydana gelmektedir. Vücudun görünümünde değişiklik yapmanın yollarından biri de dövme yaptırmaktır. $\mathrm{Bu}$ değişikliklerin çağdaş toplumlarda pek çok uygulaması vardır: sosyal işaret ve sembollerin yaratılması, suç mezhepleri, ırkçılar gibi mezhepler; geçici gelenekler Yüz ve kaş makyajı veya evlilikten sonra (Hindistan'da) alnına kırmızı nokta koyma gibi geçici ritüeller (ergenlik veya evlilik) ve hükümlüleri özel dövmelerle işaretlemek gibi bedensel cezalar (Cuyper, 2010: 36). Bu sosyal ve kültürel faaliyetler, ne yazık ki dövmelerin riskleri hakkında konuşan çoğu insan ve bu sanatlara başvuranlar, genellikle sonuçlarından habersiz olan risklerle ilişkilidir. Bu risklerin çoğu ciddi vücut enfeksiyonlarını, alerjileri çeşitlerini ve vücudun o bölümündeki değişikliklerini içerir. Farklı toplumlara göre farklı işlevlere sahip olan bu beden yazıları çekicilik için birer araçtır ancak çoğu zaman hala bir tür aidiyet ya da ayrılık yaratma ritüeli olarak kabul edilmektedir. Bu araçlar, kişinin sembolik olarak bir topluluğa, kabileye vb. katılmasına neden olur. Ayrıca onu çevresinin doğasından da ayırır. Bu araçlar, insanı dünyadaki toplumsal konumuna yerleştirerek insan yapar. Örneğin Batı Afrikalı Pavialar, vücutlarında açtıkları yaralar olmadan orman hayvanlarından ayırt edilemeyeceklerine inanırlar. $\mathrm{Bu}$ yazılar bazen toplumun değerlerini ve herkesin toplumsal yap1 içindeki meşru konumunu hatırlatmaktadır (Lubroton, 2014: 87-89). Ancak görünen o ki günümüz toplumunda bu vücut deformasyonlarının birçoğu yok ya da eski işlevini yitirmiş̧ir; ancak bu azalan örnekler arasında tatto ve dövmeler veya makyaj türleri hâlâ insanlar arasında özel bir yere sahiptir.

\footnotetext{
${ }^{2}$ Vücut Modifikasyonu, Vücut Değişimi.
} 
Tatto ve dövme kelimeleri eş anlamlı değildir. Tatto, resimlerin vücuda nakşedilmesidir. Tatto kelimesi ilk olarak Chambers'ın İngilizce etimolojik sözlügünde dövme anlamında veya deri üzerine resim çizme için kullanılmıştır ve kavramsal eşdeğeri sembol ve damgadır³ ${ }^{3}$ Sözcüğün Polinezya halkının dilinde dövme kelimesinin tekrarlanmasından kaynaklanmış olabileceği de öne sürülmüştür. Bir resmi vücuda veya dövmeye uygulamanın birkaç yolu vardır ve tatto bunlardan biridir. Dövme uygulaması ve dövme kelimesi birçok etimolog tarafindan araştırma konusu olmuştur. Bazıları köklerine davul olarak atıfta bulunurken, bazıları da gece bir barda malzemelerin veya topların tahta bir fiçının hızlı bir şekilde ateşlenmesi anlamına gelen Hollanda köklerinden türetilmiş bir kelime olduğunu düşünmektedir. Terimin başka bir tanımı, Kaptan Cook'un dövmenin cildi renkle işaretlemek için kullanıldığı Tahiti gezisine kadar uzanmaktadır (Cuyper, 2010: 30). Dehkhoda'nın sözlüğünde tatto, dövme kelimesinin eş anlamıdır ve "insanı çiçek, hayvan veya harf şeklinde tasvir etme uygulamasıdır". Ve bu iğneleme yerine deriye çivit

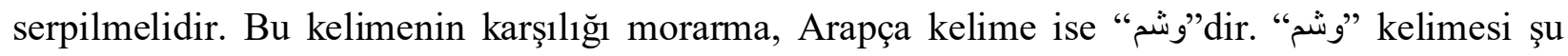
anlama gelir: Vücudun cildinin travma ve kürtajdan renk değişikliğii dövme. Ellerde ve vücutta noktalar ve çizgiler. Onun fiili ise hali çarpmadır (zarb babındandır).

$\mathrm{Bu}$ makalede dövmenin tarihçesi anlatıldıktan sonra, Franz Boas'ın sanat antropolojisindeki yöntem ve teorileri uygulanarak dövme sanatının biçimsel özelliklerini ve estetik değerlerini açıklamanın yanı sıra, bu sanatın İran toplumunun kültürel ve sosyal yapısındaki bazı işlevlerini inceleyeceğiz. Ayrıca bu yönteme dayalı olarak inceleme yapmadan önce dövmelerin sanat olup olmadığına dair notlar ekleyerek dövmeler ve sanat kapsamına alınması konusunda çeşitli kaynakların çevirilerine yer verdik. Bu nedenle dövme ve sanat alanındaki mevcut çalışma; Dövme sanat mıdır? Çoğunlukla dövmelerle ilgili kitap şeklinde yayınlanmış eserlerin tercümesine dayanmaktadır.

Bu konuyu ele almanın önemi, bir yandan çağdaş İran toplumunda özellikle gençler arasında bir sanat mesleği olarak dövmelerin yaygınlığının yadsınamaz olması ve diğer yandan dövme araştırmalarının batı çalışmalarında daha fazla mevcut kaynaklarla uyumlu olmasıdır. Bu sanat da diğer birçok sanat gibi her toplumun kendine özgü bölgesel ve kültürel özelliklerine sahiptir. Bu nedenle bu çalışmadaki amacımız, sanat antropolojisi alanında dövmelerle ilgili iki temel soruyu cevaplamaktır: Bu dövme konusu göz önünde bulundurularak sanatın alışılmış estetik özellikleri

\footnotetext{
${ }^{3}$ To mark: işaretlemek-damgalamak, çizmek.
} 
ne ölçüde elde edilebilir? İkinci olarak, dövmelerin kültürel ve sosyal yapısında estetik özelliklerinin yanı sıra kültürel ve sosyal aidiyetleri de incelenmiştir.

\section{Araştırmanın Arka Planı}

Dövme üzerine yapılan araştırmalar birkaç kategoriye ayrılmıştır. $\mathrm{Bu}$ araştırmaların bir kısmı betimsel olarak ilerleyerek tasarımları tanımlayıp kategorize etmekte ve sadece bu sanat dalındaki tasarımları ele almaktadır. Bu açıklamaların daha çok İran dışı dövmeler üzerine yapılan araştırmalardan oluştuğunu belirtmekte fayda vardır. Bu çalışmalardan biri örnek olarak, "Tattoo Bible Insider Secrets to Awesome Looking \& Everlasting Tattoos" kitabı, bu sanatın tasarımı ve uygulanması ve bu çalışmanın farklı kişiler arasındaki amacı hakkında bazı temel soruları yanıtlamaktadır. Bu kitap, insanlardan seçtikleri rollerden emin olmalarını isteyerek dövmelerin kalıcılığı konusunu ele almaktadır.

Deri hastalıkları patolojisi alanındaki diğer araştırmalar da bu sanatlar arasında dövme ile ilgili sanatlan içermektedir. Vücut sanatları ile ilgili cilt hastalıkları kitabı ${ }^{4}$ dövmeler, kalıcı makyaj ve piercingler olmak üzere üç bölümde düzenlenmiştir; her bölümde, bu sanatların her birinin halk arasında tarihçesi ve öğrenilmesi incelendikten sonra bu eserlerin meydana getirilmesi ve ortadan kaldırılmasına yönelik teknik ve araçlar ile bu sanatın başlıca (ileride yol açacağı) tehlikeleri incelenmiştir. $\mathrm{Bu}$ araştırmaların üçüncü kategorisi dövmelerin kültürel ve sosyal kökenlerini tanıtmakta ve tartışmaktadır.

Vücut dönüşüm süreci "Dövme Sanat1 ve Kültürü”5 kitabı: dövmelerin sosyal dünyası, dövmeli kişilerin durumu, toplumda para kazanmanın bir yolu olarak dövmeler, dövmeler ve bu sanatın sosyal tanımları, giriş ve tartışma hakkındadır. Bu araştırmanın sonucu, tıpkı üretim nesnelerinin bir kültürün ekonomik karşılıklı ilişkileri bağlamında şekillenmesi gibi dövmelerin toplumsal dünyasının da bu sanatın kendine özgü kültürel ürünlerinin merkezi etrafında şekillendiğini vurgulamaktadır. Dövmeler ve bireysel suistimal arasındaki ilişkiyi incelemeye ek olarak, bu kitap aynı zamanda dövmelerin sosyal özelliklerini de açıklamaktadır. Çünkü dövmeler tipik olarak sanat gibi kültürel etkinliklerin diğer birçok özelliğini örnekleyen özelliklere sahiptir. Yazar başka bir çalışmada özellikle kadınlar arasında dövme gibi dekoratif özelliklere değinmekte ve

\footnotetext{
${ }^{4}$ Cuyper, Perez-Cotaps, Dermatologic Comlications with Body Art: Tattoos, Piercings and Permanent Make.

${ }^{5}$ Sanders, Customizing the Body (the Art and Culture of tattooing)
} 
dövmelerin kültürel özelliklerine atıfta bulunarak vücut duruşundaki bu değişikliği vücuttaki kalıcı değişikliklere örnek olarak ele almaktadır. ${ }^{6}$

Çalışma, dövmelerin Batılı olmayan kültürlerde bir eylem olarak üç genel amacı karşıladığı̆ıı bulmuştur. Bu hedeflerden biri dini uygulamalarla ilgilidir, diğeri ortak eylem ve becerilere sahip bir grubun üyelerini belirlemek için dövme yapmak ve üçüncüsü, dövmelerin kabile kültürlerinde ana işlevi ve koruyucu ve büyülü özellikleridir.

Bu makalenin kadın ve dövmeler bölümünde popüler tasarımlar konusu ve kadın ve erkek arasındaki tasarım seçimlerindeki farklılıklar da ele alınmaktadır. Bu alandaki metodolojik ve teorik çalışmaların, kendi kültürel ve tarihsel tarzı ve bağlamı ile bir sosyal eylemin dövmesinin, antropologların çalışmalarının konusu olan ayrıntılı açıklamaların ve salt sembolizmin kapsamı dışında olduğu durumlarda ortaya çıkması daha olasıdır. Franz Boas gibi antropologların bu konudaki araştırma faaliyetleri, dövmeleri teknik ve kültürel alanlarda gelişim ve evrim aşamalarından geçen ilkel toplumlardaki ritüel uygulamalar ve sanatsal gösterilerin bir örneği olarak görmektedir. Bu alandaki bilimsel metodolojik çalışmalar, İran dışı araştırmalarda uzun yıllar bulunmasına rağmen, dövmeler konusunda ülkemizde henüz yer almamıştır. Bu nedenle bu çalışma, bu sanatın dünyadaki tarihini belirttikten ve çağdaş İran toplumundaki temel özelliklerini Boas yöntemiyle sanat antropolojisinde ele aldıktan sonra estetik özellikleri ve toplumun sosyal yapısındaki rolünü incelemektedir.

\section{Dövmelerin Tarihi}

Binlerce yıldır çeşitli kültürler, vücudun fiziksel deformasyonunun varlığını sosyal etkileşimler sürecinde gizemli ve sembolik anlamın yaratılması nedeniyle kalıcı veya geçici olarak reva görmüş ve bazen kınamıştır. Saç stilleri, giysiler, özel makyaj ve diğer değişken yüzler gibi geçici değişiklikler yapmak, genellikle belirli ve değişken bir durumda bireysel kişiliği tanımaktır. Aslında insan statüsünün normal sürecinin kesintiye uğraması ve bozulması bazen bir kişiyi belirli bir sosyal alt grubun üyesi olarak yerleștirir (Sanders, 1991: 147). Bu ifade yalnızca bu kararsız biçimler bir toplumda anormal anlamlar ürettiğinde geçerli değildir. Bazen dini törenlere katılmak

\footnotetext{
${ }^{6}$ Sanders, Memorial decoration: Women, tattooing, and the meanings of body alteration.
} 
için insanların kıyafetlerini değiştirmek ve toplumun normlarına uygun kutsal yerlere girmek bile onları dini bir grubun parçası yapar.

Bizim kültürümüzde ve diğer kültürlerde kadınlar makyajı güzelliklerini vurgulamak, geliştirmek ve özgüvenlerini artırarak çevrelerini etkilemek için kullanırlar (Sanders, 148). Ancak bu davranışlar bazen günlük aktiviteleriyle sınırlıdır. Halbuki erkekler bu makyajların sembolik yönüne daha çok önem verirler; daha gizemli ve sembolik anlam taşıyan dövmeler veya çizimli tasarımlar seçerler.

Toplumda belirli ve bazen farklı bir makyaj seçmiş kadın ve erkeklerle konuştuğumuzda, kadınlar konuşmalarının başında güzelliklerine işaret ederken erkekler bu tasarımların referans noktasını tarif etmeye ve sembolik yönünü ele almaya başlar. Franz Boas, Pasifik'in batı kıyısı üzerine yaptığı araştırmada, anlamlı (sembolik) sanat ile dekoratif zevk taşıyan sanatlar arasındaki ayrımları ifade ederken ilkini eril, ikincisini dişil olarak değerlendirir. Vücuttaki sürekli değişimlerin kişinin yaşamı boyunca sosyal statüsünü etkilediği için daha fazla sembolizm taşıdığı açıktır. Çoğu kültürel bağlamda insan vücudunun delinmesi, yaralanması, dövülmesi ve şekillendirilmesi, bireylerin sosyal bilişlerinde bazen ritüellerle ilişkilendirilen kalıcı değişiklikler arasındadır (Sanders, 1-3). İlkel kavimler arasında bu davranışlar ve değişiklikler bazen hayatın bir aşamasına girmek, bazen de hastalıkları tedavi etmek (ağrı hapsi) için kullanılmıştır. Örneğin Brunei kadınlarının bacakları ve kolları, geleneksel hayvan tasarımlarıyla güzelce dövmelenmiştir. Belirtildiği gibi dövmeler ve tatto ve genel olarak vücut boyama, birbirleriyle eşanlamlı olmasalar da kültürlerde ve dünya uluslarının büyük çoğunluğunda uzun yıllardır alışılagelmiş ve hâlâ yaygındır. Yüzyıllar önce bir kabilenin üyeleri, kendilerini diğer kabilelerden ayırt etmek için farklı işaretler ve semboller kullanmıştır. Bunlar, örtü tipini, özel makyajı ve dövme kullanımını içermekte idi. Bu semboller kabilenin ileri gelenleri tarafından seçilmiş ve insanların bunları kullanmaları istenmiştir (Samani, 2010).

Dövme yapılan en yaşlı beden, 5300 yıl önce Neolitik dönemde yaşamış bir adama aittir. $\mathrm{Bu}$ adamın 15 dövmesi mevcuttur. Omurga boyunca paralel uzanan iki turkuaz mavisi çizgi, bel ve bacaklarda birkaç dairesel çizgi şekli ve sağ dizinde küçük bir haç şeklinde desen, Otsey'nin vücudunda bulunan dövmelerden bazılarıdır. Ayrıca Mısır mumyalarının vücutlarında çeşitli dövmeler vardır. 4000 yıl önce Mısır'da yaşamış Amont isimli bir kadın rahibin ellerindeki dövmeler gibi (Parry, 2006: 12) (Resim 1). 
Susa bölgesinde bulunan Hammurabi yasalarını içeren taş tablet, dövme konusunda bilinen en eski belgedir. Hammurabi kanununun maddelerinden birinde; "Bir kimse, kölenin vücuduna, sahibinin ve efendisinin izni olmadan satmasını engelleyecek şekilde dövme yaparsa, dövme yaptıran kişinin parmakları kesilmelidir" yazmaktadır. Ayrıca 227. maddeye göre "Eğer bir damgacı aldanır ve başkasına ait olan bir kölenin vücuduna affedilmez ve satılmasına engel olacak bir işaret damgalarsa, bilerek damgalamadığına dair yemin etmeli ve aldatan kişiye mahsus olan ceza onun hakkında uygulanmamalı.” (Samani, 2011).

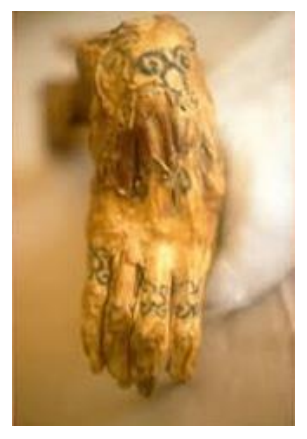

Resim 1. Ammont el dövmesi (Samani, 1389)

Eski zamanlarda dövme yapmak bir ritüeldi. Zaman zaman bu yöntem belirli bir mezhebe veya dine mensup kişileri belirlemek için kullanılmıştır. Mısırlılar, Gotlar ve Yunanlılar, gerektiğinde teşhis edebilmeleri için kölelerinin, mahkumlarının ve tutsaklarının vücutlarına özel işaretler dövmelerdi. Almanlar, Üçüncü İmparatorluk’ta Yahudilere ve eşcinsellere dövme yaptırmıştır. Hıristiyanlar alınlarına, kollarına veya omuz eklemlerine İsa Mesih'in adını veya yıldız, haç, balık gibi dini sembolleri dövmeleyerek Hıristiyanlığa bağlılıklarını kanıtlamışlardır. Haçlılar, derilerine haç dövmesi yaptırmazlarsa ve Müslümanlara karşı savaşta öldürülürlerse ebedi barışa asla kavuşamayacaklarını düşünmüşlerdir. Denizciler, sokak satıcıları, serseriler, üs (SS) askerleri, Fransız lejyonerleri, serseriler, suç çeteleri ve Yakuza mafyasının üyeleri kendilerine dövmeler yapmışlardır. Bu grupların daimî üyesi olduklarını göstermişlerdir. Bu gruplarda yarasa, kartal, akrep ve yılan tasarımları genellikle ilgili grubun sembolü olarak dövmelenmiştir. Bu yüzden Hintli kadınlar yüzyıllardır alınlarına dövme yaptırmaktadır (Samani, 2011). 
Yaklaşı 150 yıl önce dekoratif dövme Japonya'da popüler hale gelmiştir. Aerosonic dövmeler, hırsızların ve isyancıların hikâyelerinden ve eski Asya ve Çin mitlerinden motifler kullanmıştır. $\mathrm{Bu}$ efsanelerin tarihi on dördüncü yüzylla kadar uzanmaktadır. İrozoik tarzındaki en önemli çizimler ejderha, kiraz çiçekleri, kaplan, leopar ve maymundur. Bu çizimler Japon mitolojik dünyasının ve mitlerinin ruhuna uygun bir şekilde bir araya gelmelidir. Bugün en ünlü dövme sanatçılarından biri Tom Lepard'tır. Tom Lepard, vücuduna leopar derisinin çizimini dövmelemiştir. Bu kişinin vücudunun sadece yüzde on birine dövme yapılmamıştır ve bu açıdan dünya rekorunu elinde tutmaktadır (Samani, 2011).

\section{Teorik Desen ve Yöntem}

$\mathrm{Bu}$ makalede, Alman antropolog Franz Boas'ın erken dönem sanatının özellikleri üzerine betimleyici-analitik bir kuramsal model kullanılmıştır. Boas'ın yaklaşımı iki ilkeye dayanmaktadır. Birincisi, bugün tüm insanların zihinsel akımları temelde herhangi bir ırk veya kültürle aynıdır. İkincisi, tarihsel olaylar gibi tüm olgularda gözlemlenebilirdir (Boas, 2012: 43). Sonuç olarak her stil, herhangi bir toplumla ilişkili muhafazakâr bağlamda ve metinde gelişmektedir (Boas, 33-34).

Boas, farklı kültürel bağlamlarda farklı estetik değerlere işaret etmenin yanı sıra yürütme becerileri ile güzellik duygusu arasında yakın bir ilişki olduğuna da dikkat çekmektedir. Ona göre vücudun veya nesnelerin ritmik hareketleri, ilginç şekiller, sesin yumuşak yankılanması ve sessiz bir konuşma biçimi, bir tür sanatsal üretim olarak kabul edilmektedir. Bir yandan teknikler dizisinin uygulanmasındaki ustalık, sonunda belirli biçimlerin üretilmesine yol açacak kadar büyük olduğunda sanat eserinin yaratıldığını söyleriz; Öte yandan sanatsal ve yarı-sanatsal formlar arasındaki kesin sınırı belirlemek çok zordur. Çünkü estetik davranışların başlangıç noktasını tam olarak belirlemek imkansizdır (Katak, 2008: 712; Boas, 2012, 53-55)

Boas, estetik etkinliğin bir dizi biçimsel özelliğini şöyle tanımlamıştır: düzen, simetri ve ritim. Yerlilerin eserlerinde özensizlik olmadığını, çeşitli örneklere göre tekniğin icrasında maharet ve ustalık eksikliğinin görünen düzeni bozduğunun görüldüğünü söylemektedir (Boas, 2012: 73). Tüm çağların ve kabilelerin sanatında gözlemlenen bir başka özellik de simetridir. Bu simetri en basit dekoratif şekillerde görülmektedir. Simetrik şekillerin yaygın olarak kullanılmasının ana nedenleri iyi anlaşılmamıştır. Boas, simetrik elemanların çoğunu dikey eksen simetri grubuna ve 
nadiren yatay eksen simetri grubuna yerleştirmiştir. Ayrıca, çoğu dairesel şekilde simetri ekseni için şeklin çapı kullanılmıştır (Boas, 85-89). Bu düşünür, süsleme sanatında sayısal veya alfabetik numaralandırma yöntemini kullanarak ahenk olgusunu ortaya koymuştur. Böylece kompozisyon türünün şekli ve yöntemi ve özellikle dekoratif sanat unsurlarının nasıl bir araya getirileceği açıklanabilmiştir. O, Düzenli hareketlerin, aynı kalıpların düzenli ve ritmik tekrarına yol açan tek tip bir yüzey oluşturduğuna dikkat çekmektedir. Bazen motifler dizisi, biri şekiller, diğeri renkler için olmak üzere iki ayrı ahenktir. Tekrarlanan şekiller genellikle motiflerin dizilişidir, biri şekiller diğeri renkler için olmak üzere iki farklı ahenktir. Tekrarlayan şekiller genellikle yatay olarak yerleştirilir, bu da arka arkaya düzenlenmiş basit bir desen tasarımı oluşturma adımlarını göstermektedir (Boas, 97-112).

Bu makalede, Boas'ın yöntem ve teorilerini kullanarak estetik faaliyetleri biçimsel özelliklerinin belirlendiği şekliyle inceledikten sonra dövme sanatçısının bakış açısının anlamı ve bu tasarımların anlamı arasında kaçınılmaz bir ilişki olduğunu ve aynı şekilde bu dövmeleri vücuduna yaptıran kişinin bakış açısından da incelenmesinin imkânsız olduğunu ve bu kişinin hem sanatçının tuvali hem de ilk izleyicisi ortaya çıkıyordur. Her ikisi de sosyo-kültürel yapı ile bağlantılı olacaktır.

\section{Dövme ve Sanat; Dövme Sanat Mıdır?}

Bu bölümdeki amacımız, bazı sanat öğretilerini ve dövmelerle ilgili düşüncelerini gözden geçirmektir. Dövmeleri düşündüğünüzde, dövmeler bir yüzeyde görüntülenen görüntülerdir; halbuki Da Vinci gibi sanatçıların resimleri de tuval gibi bir yüzeyde sergilenmektedir! Ama aralarındaki fark nedir? Dövme hangi sanattır? Her zaman sanat araştırmacıları ve sanat eseri ile uğraşanlar arasında çoğu insan sanatın ne olduğunu bilir ama tanımlayamaz.

Dünya sanatı teorisinde sanat, dünya sanatıyla ilişkilidir. Sanat dünyası, sanat tarihi, sanat geleneği ve sanatçılarla ilişkilendirilebilecek bir şeydir. Fakat dövme bu teoride bir sanat mıdır? Sanat müzelerini, sanat tarihini ve sanat eleştirisini düşündügüumüzde dövmeleri nadiren düşünürüz veya belki de hiç düşünmeyiz. San Francisco'daki dövme müzesine rağmen bu müze herhangi bir sanat tarihi müzesinden çok daha fazla ortaya çıkmaktadır. (San Francisco'da bir Dövme Müzesi olmasına rağmen bu müze, diğer sanat tarihi müzeleri arasında çok daha yeni sayılmaktadır.) Dolayısıyla sanat dünyasının standartlarına göre dövmeler sanat değildir (Arp, 2012: 55). Ancak 


\section{Çağdaş Kültürel ve Sosyal Yapıda Sanat Olarak Dövmelerin İncelenmesi}

çağdaş dünyada dövmelerin her zaman büyüdüğü ve sanatçıların dövmeleri sanat alanı dışında düşünmelerinin zor olduğu unutulmamalıdır.

Biçimci sanat teorisi, bağlam ve sanatçı ve izleyici ile ilişkisi ne olursa olsun ve yalnızca bir sanat nesnesi olarak dövme temsilini incelememize yardımcı olmaktadır. Biçimci kuramlara göre sanat biçimsel özelliklerin sonucudur. Dövme imgeleri kombinasyon halinde estetik duygu uyandıran çizgi, gölge, boyut ve perspektif gibi görsel özellikler açısından biçimci teorilere dahil edilebilir. Aslında biçimciler dövmeleri tek görsel sanat olarak kabul etmektedir (Arp, 56-55). Ancak bir dövme muhatabıyla, konusuyla ve kişinin dünya görüşünün bağlamı ve türüyle herhangi bir bağlantısı olmadan gerçekten düşünülebilir mi?

Tolstoy, ifade teorilerinin (dışavurumculuk sanatı) sunumunda evrensel duygudan bahsetmektedir. Sanatçıda ilk olarak ortaya çıkan duygu eserinde ifade edilmekte ve izleyiciye aktarılmaktadır. Dövmeler dişavurumcu öğretilerde daha güçlü hale gelmiştir. Bir kişinin vücudundaki dövmelerin, bağımlılıklar, ilişkiler ve dokular ekleme yeteneğiyle dolayısıyla anlam yaratmayı mümkün kıldığı gerçeği mevcuttur. Arp bir örnek vermektedir: "Omzuna kırık zincir dövmesi yaptıran bir arkadaşım var. Bu görüntü tek başına bir anlam ifade etmeyebilir. Ancak bu kişi, bu resmi tam olarak vücudunun eşi tarafından yaralanmış olan kısmına dövme yaptı. Böylece resim tuvali (bireysel), izleyiciye derin duyguların bir özetini getiren sanat eserine derin ve kesin bir anlam kazandırmaktadır" (Arp, 56).

Şimdi dövmelerin bir kişinin vücuduna yapıldığını ve bu yönün tasarımdan veya ifade edilme biçiminden daha önemli olduğunu düşünürsek dövmeler görsel sanat değil, performans sanatı olarak kabul edilir. Örneğin sahne sanatlarında şarkıcı dans ederken, yürürken veya sesini değiştirirken bir şiir söyler. Artık tuvaldeki kişi düşünüldüğüne göre dövme, performans sanatı olarak kabul edilebilir; hareket eden ve değişmekte olan sanattır (Arp, 2012: 58; Sanders, 1989: 151). Dövmelerin bir gösteri sanatı olarak görülmesinin önemli nedenlerinden biri çok az sayıda dövme örneğinin gerçekten özgün sanat eseri olmasıdır (Arp, 2012: 59). Çoğu dövme tasarımı insan vücudundaki tuvalin kopyalarıdır. Tek mesele görüntünün estetik olarak değerlendirilmesi ise o zaman görüntüye değinmek uygun olur ve asıl eser ilk iştir. Artık mantıklı bir şekilde dövme için tasarlanan görüntünün nihai iş değil, sadece ilk tasarım olduğu söylenebilir. Ve bu görüntünün kişisel bir vücuda her dövmelendiği zaman orijinal bir görüntü mü yoksa bir kopya olarak mı ve sadece ilk kişinin vücudunda mı olduğu sorusu ortaya çıkmaktadır? Bu soruya yanıt olarak her insanın bir dövme tuvali gibi benzersiz bir varlık olduğunu ve bu kişinin diğerinden bağımsız 
hareket ettiğinin söylenemeyeceği unutulmamalıdır. Ve sanatı temsil eden tuval her biri için farklıdır ve farklı bir yolu ve anlatımı vardır.

Örneğin, Mona Lisa'nın çok gerçekçi bir kopyasını düşünün ki bu zaten orijinal olmayacaktır. Ama Marcel Duchamp Mona Lisa'ya bıyık bırakırsa durum farklı olacaktır. O bıyıkla Mona Lisa gülüşü aynı anlama gelmemekte, etkinin dokusu ve anlamı değişmektedir. Yani her dövme kopya olsa bile farklı bir kişinin vücuduna dövme yapıldığı için farklı bir anlam taşımaktadır. Dövme sanatının anlamını aşağıdaki bölümlerde daha ayrıntılı olarak ele alacağız. Dövmelerin bu yorumları formalist öğretilerle uyumlu olmasa da dövmeler, tuvali anlam yaratan gelişen bir sanattır ve tek başına resimler, resmin tam anlamını iletmek için yeterli değildir.

Söylenenlere göre dövme sadece çağdaş toplumumuzda değil günümüzde diğer toplumlarda ve herhangi bir toplumda kabul görmüş bir sanat eseridir ve o toplumda özel bir üslup olarak tanımlanmaktadır. Özel kültürel özellikleri ve çevresel yapısı göz önünde bulundurularak bilimsel yöntemin bu sanatı çağdaş toplumunda incelemek için kullanılabileceği anlamına gelmektedir.

\section{Dövme Tasarımlarında ve Desenlerinde Biçimsel Özellikler}

\section{-Düzen}

Dövme tasarımları ile ilgili olarak Mısırlı rahibe Amount'un vücudundaki dövmeler gibi geçmişten gelenler, kuşkusuz sanatçının becerisinin bir göstergesi olan gözlemlenebilir bir düzendir, ancak bu sanat insan vücudu ve bunlarla ilgili olduğu için tasarımlar kalıcıdır. Bu motifler arasında sanatçının tekniği ve becerisinin çıkmazından motifler vardır ve ancak sanatçının ya da bu tasviri üzerinde taşıyan kişinin yardımıyla tasvir belirlenebilir.

Bugün bile bu sanatta desenlerin ve çeşitli kombinasyonların düzen ve aranjmanlarının oluşturulması, sanatçının becerisinin yanı sıra bilimsel gelişmelerle hem tasarım aşamasında hem de kalıpların icrası aşamasında sanatın hizmetinde kullanılmıştır. Bazen şablonları hem geometrik hem de gerçekçi tasarımlarda kullanmaktayız (Resim 2). 


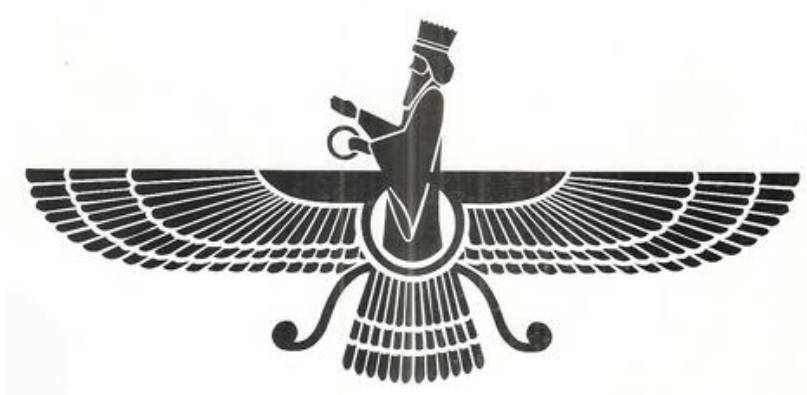

Resim 2: Faravahar (www.tatoonh.com)

\section{Simetri}

Dövme için seçilen tasarımlarda Boas'ın bulgularında olduğu gibi simetri daha çok dikey eksen etrafındadır. Örneğin kelebeğin vücut üzerindeki rolü bariz bir simetriye sahiptir. Elbette doğrusal motifler ve geometrik desenlerdeki simetri de genellikle dikey eksen etrafındadır. Dikkat çekicidir ki bu tablonun tuvali bedendir ve tuval tüm parçalarıyla simetriktir ve alışkanlıklarımız da vücudumuzun simetrik hareketlerine dayandığı için simetrik desenlerin kullanımı bu kadar ileri gitmektedir. Bu bazen her iki uzuvda simetrik olarak iki özdeştir ama ayrı ayrıdır ve bazen iki uzuv, örneğin iki bacak yan yana getirilerek simetrik rol tamamlanmaktadır. Unutulmamalıdır ki günümüzde yeni teknolojiler bu konuda insanların yardımına yetişmiştir.

Süsleme sanatı, desen kullanımını içerdiğinden özellikle tasarımın tekrarından ve simetrik düzeninden elde edilen bileşenin başka bir bileşenle olan belirgin ilişkilerini kullanır (Jal, 2012: 121). Kuş kanadı görüntüsünde (c.3), gövdenin dikey ekseni etrafındaki iki kanadın simetrisi görülmektedir. Vücuttaki balık görüntüsünde (b.3) simetri de vücudun simetrisi ile yaratılmıştır. Ayrıca vücudun iki ayrı ama simetrik parçasının bir arada yerleştirilmesi de görüntüyü tamamlamaktadır. Soyut tasvirde (a.3) dikey eksen etrafındaki simetri de tam olarak gözlenmektedir. 

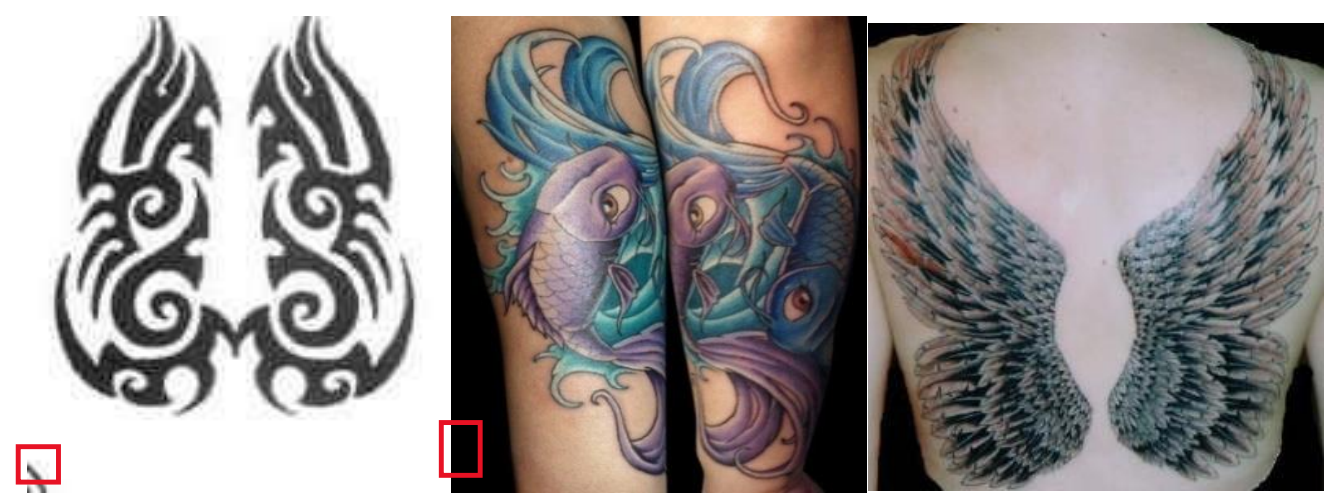

Resim 3.a: Kabile rolü olarak bilinen soyut rol, b: balık rolü, c: kuş kanadı rolü (www.alrmal.net; www.trendhunter.com)

\section{Ahenk}

Dövme tasarımlarında hem düzene bağlı hem de biçimde düzen ve güzellik yaratan ahenk olgusu görülür; ya da buna uyulmaya çalışılır ama bunun genel bir kuralı yoktur ve kültürel bölgeler onu manipüle edebilir.

Resmin (4.b) soyut rolü, kabile motifleri olarak bilinen motifler arasında görülmektedir. Bu rol, resimde çift $(b, a)$ ile gösterilen bir ahenge yol açan düzenli bir tekrara sahiptir ve bu ahenk bir dönme ekseni etrafinda kurmuştur. Kişinin sırtına dövme yaptırılan kuş kanadı (4.a) tasvirinde, kuşun tüylerinin ahengi (b, a) harfleriyle tekrarlanarak görüntünün bir parçası gösterilmiştir.
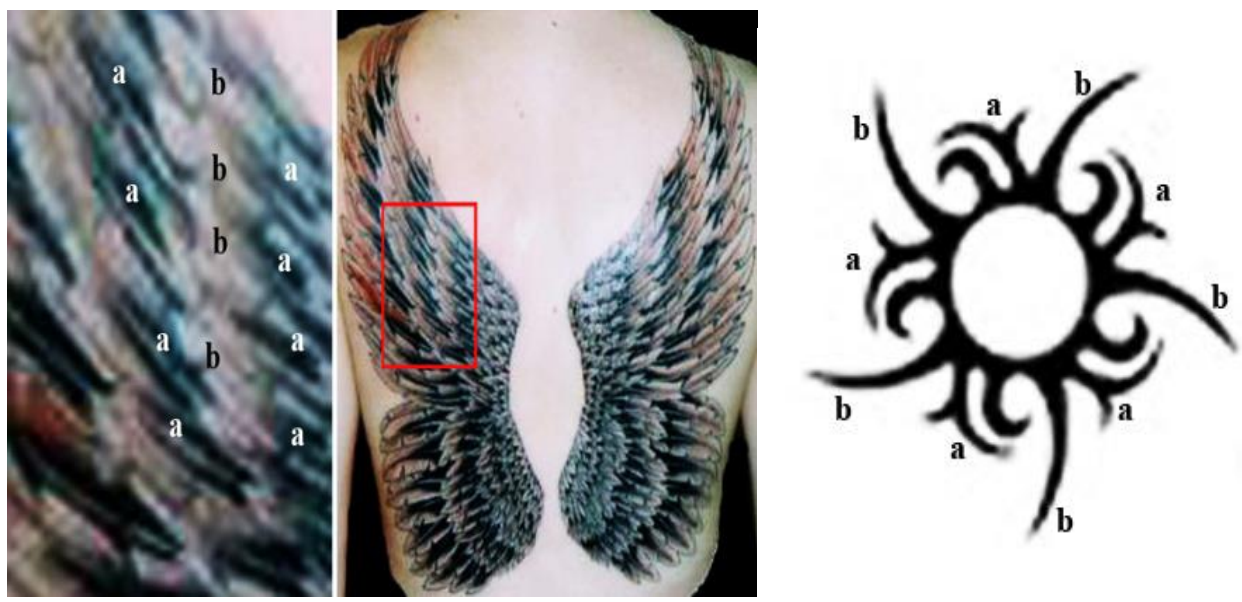
Resim 4.a: Kuş kanadı rolünün bir bölümünün büyütülmüş hali, b: Soyut rol-Kabile (www.alrmal.net; www.trendhunter.com)

Nesneleri süslemenin bir başka yaygın yolu da kenarlarını süslemektir. Çoğu durumda bu tür bir dekorasyonun teknik bir nedeni vardır. "Dekorasyon doğası gereği işlevseldir, aksi takdirde varlığı açıklanamaz" (Jal, 2012: 121). Ancak her zaman teknik cebir değildir ve nesnelerin kenar boşluklarında motiflerin kullanılması isteğe bağlıdır, varlıklarının tek nedeni onları sunma arzusudur. Bu tür motifler çok nadirdir ve her zaman çok özeldir (profesyonel olarak sunulur). Marjinal tasarımlar oluşturmak bazen nesnenin biçimsel değerini yükseltmek amacıyla yapılmaktadır. Bazen sınırları belirlemek için kenarların çevresel boşlukları kalınlaştırılmaktadır. Bu tasvirleri içeren şeritlerin yavaş yavaş gerçek dekoratif mekânlar haline geldiği ve hem mekânı hem de dekoratif alanı sınırlamak için kullanıldığı sıklıkla görülmektedir. Yüzeyin kendisi dekore edilmişse, bu dekoratif çizgiler veya şeritler dekorasyon alanını sınırlandırmak ve belirlemek dahil olmak üzere daha kullanışııdır. Bu durumda objenin her bir parçası ayıı bir dekoratif alan olarak kabul edilmektedir (Boas, 2012: 123-118).

Tasarımı sınırlandırmanın yanı sıra kelebek kanadı bordür tasarımının büyütülmesi de resim beşte gösterilmiştir. Bahsedilen dövmeli çiziminde, yıldız şekline sahip noktalar ve şekillerden marjinal tasarımlar olarak bahsedilebilir.
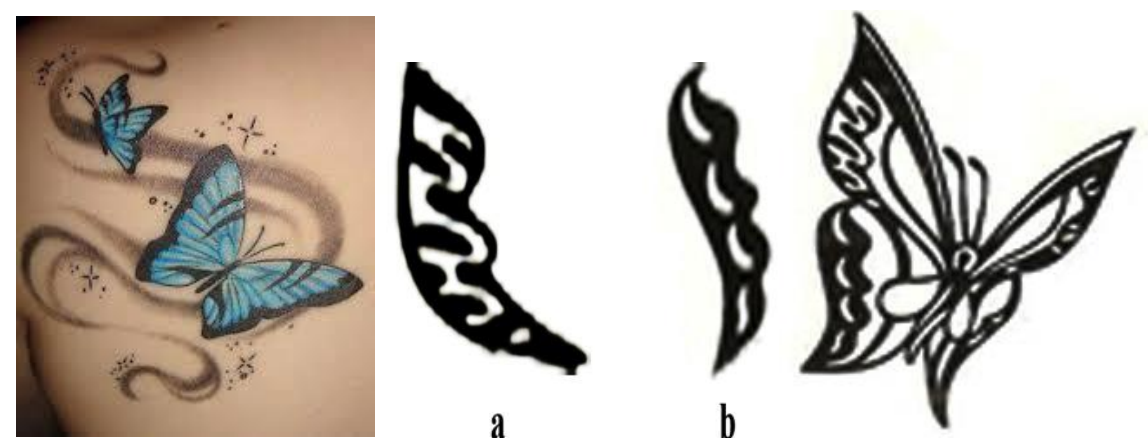

Şekil 5. Kelebek rolündeki marjinal tasarım (www.bodygrafixtattoo) 


\section{Dövme Tasarımlarında Sembolik Anlam ve Değerler}

Dekoratif motiflerin sosyal, kimlik ve güzellik anlamları vardır ve tüm motifler için çok karmaşık bir anlam aramamalıyız. Çünkü insan her şeyi sembolik bir anlamla deneyimlemez, aynı zamanda dekoratif bir yönü de vardır. Katak, insanların aldıklan metinlere ve ürünlere kendi anlam ve değerlerini yüklediğini ve bu anlamların deneyimlerinden ve kültürel bağlamdan türetildiğini ancak yerel kültüre uyum sağlayan diğer kültürlerden de bazı unsurların girişinin meydana geldiğini işaret etmiştir (Katak, 2007: 823). Kullanılan süs eşyaları, dünyadaki kabile akrabaları arasında özel bir değere sahiptir. Aslında anlamlıdırlar ve bu durumda da yorumlanabilirler (Boas, 2012: 159). Ayrıca toplumdaki her eylemin anlamsal katmanları vardır. Bu semantik seviyeler geri alınabilir ve bir dereceye kadar yeniden yapılandırıcıdır ancak davranışsal anlamı anlayamasak bile anlamsızlık yoktur. Dolayısıyla bu tür eserlerde dekoratif ya da sembolik bir fikrin olduğu söylenebilir.

Buzdan heykeller ve müzik gibi bazı sanat eserleri bize bir noktada estetik deneyim kazandırsa da dövmeler bir kişiye ölene kadar eşlik etmektedir. Dolayısıyla kişinin vücuduna yerleştirilen sanat onun için çok anlamlı olacaktır (Arp, 2012: 36). Dövmeler vücuttaki değişikliklerle ilişkilidir. Kişi yaşlandıkça dövme yıpranır ve çürür ve kişi öldüğünde dövmeli rolü de azalır. Çoğu durumda dövme, görsel ve estetik birliği ve uyumu gösterir ve biçimcilerin istediği de budur. Aynı zamanda sanatçının, tuvalinin (bireysel bedeninin) veya her ikisinin de duygusal içeriğini ifade etmektedir. Ve ölüme kadar inkâr edilemez bir ahit olarak bireyle birliktedir. Arp dövmeyi anlamlı bir sanat olarak görmektedir. Çünkü onda görüntünün bütünlüğünü, görüntünün anlamını ve onun tuvalinin yaşamından ve ölümünden ayrılmaz bir şekilde uygulanışını görmekteyiz. Böylece dövmeler sanat dediğimiz şey için gerekli anlam katmanlarına sahiptir (Arp, 37).

İnsan vücudundaki dövmeler arasında kartal gibi hayvanların tam görüntüleri, aslan gibi hayvan başları, kelebekler, balıklar, akrepler vb. gibi kolayca tanınabilen nakışlar vardır. Bu motiflerin çoğunda kartal kanatları açık ve yüz yüze gösterilmektedir. Çağdaş İran toplumunda açıkça gösterilen motiflerden biri sembolik anlamı birey için açık olan veya olmayan Faravahar tasviridir. Çoğu örnekte göğüste veya ensede kullanılmaktadır ve bazen kartalın başı orta elemanın yerini almaktadır. Ayrıca bu resim bazen tamamen geometrik ve sembolik bir şekilde kullanılmaktadır. 
$\mathrm{Bu}$ sanatta dövme sanatçısının tuvali insan bedenidir. Eliade'ye göre kültürün belirli bir aşamasında insanın kendini bir mikrokozmos, tanrıların yaratılışının bir parçasını oluşturan ve evrende tanıdığı kutsallığın aynısını kendinde bulan küçük dünya olarak düşündüğünü kabul edersek insanın evrenle birleşmek için her zaman bahaneleri olduğunu ve bazen ritüel kutlamalar düzenleyerek ve zamanı yeniden yaratarak bazen de vücüduyla ilgili tasarımlar oluşturarak onları sembolize ettiğini ifade edebiliriz (Eliade, 1956: 91-62). Dolayısıyla güneş, yıldızlar, takımyıldızlar ve yılın farklı aylarına yönelik işaretler gibi göksel bir kökene sahip desenler yaratmada insan eylemini açıklamak mümkün olabilir.

$\mathrm{Bu}$ nedenle dövmeyi bir performans sanatı olarak düşünürsek ona baktığımızda yavaş yavaş dağılan ve özellikle hayatımızı, performansımızı ve ölümümüzü düşündüren bir eser görürüz.

Günümüz uygarlığında morfolojik değeri ne olursa olsun tasarımın renginin veya şeklinin sembolik bir anlam taşıdığı durumlarla karşılaşmaktayız. Bunlardan en belirgin olanı ülkelerin ulusal bayraklarıdır. Bayrağın görüntüsü sadece dekoratif değil, aynı zamanda duygusal çekiciliğe de sahiptir. Bu da bu fenomenin sadece görsel bir fenomen olmadığı anlamına gelmektedir.

Süslemenin yorumlanması ve anlamının etkili olabilmesi için koşulların sağlanması amacıyla herkes tarafindan kabul edilmeli ve köyün veya grubun tüm sakinleri tarafından hiç şüphesiz kabul edilmelidir. $\mathrm{Bu}$ durumlar çok nadirdir ve çoğu zaman farklı sembollerin anlamı hakkındaki görüşler sorgulanabilir. Kişi, belirli bir formun kavramını başka bir kişinin yorumundan tamamen farklı bir şekilde yorumlayabilir (Boas, 2013: 177). Bu anlamsal farklılıklar sadece zaman içinde oluşmakla kalmaz bazen belirli bir zaman diliminde farklı yerlerde farklı yorumlanır ve günümüzün uygar toplumlarında bazen kişiden kişiye farklı yorumlanmaktadır. Boas’a göre bir tasvir, bir insanda bir değer olarak kabul edilebilir ve duyguların kaynamasına neden olabilir. Ancak diğer kabileler için farklı bir algı ile aynı tasvir duygusal değeri olmayan bir semboldür. (dipnot)

Örneğin kadınlar arasında en çok dikkat çeken dekoratif tasarımlardan biri de kelebektir. Bedenlerinde bu tasvire sahip olanlara ve bu eserin sanatçısı sayılanlara göre bu tasvirin insan bedeni üzerindeki konumu, anlamını yorumlamada etkilidir. Biri kelebeğin ayak bileğindeki rolünü şöyle açıklamaktadır: "Sağ ayağıma dövme yaptıran kelebeğin rolü, iffet ve dürüstlüğün bir işaretidir. Bu böcek güzel bir böcek ve yalnız kaldığında kelebek olmak için kendi etrafina sarıldığından, bu tür yaşam saf yaşamının bir işaretidir”. Başka bir kadın, karnındaki bir kelebeğin varlığının cinsel partnerlerinin tatmin olmasına neden olduğunu ifade etmektedir”. 
Bir tasvirin yorumlanmasının bu kadar çeşitli olabilmesi veya tersine farklı biçimlerin benzer tanımlara sahip olabilmesi, tasvirleri tanımlamak için kullanılan anlamların hafife alınmaması gerektiğini göstermektedir. Bilakis ortak sanat formu ile bir dizi fikir arasında kesin bir ilişki vardır. Tasvir kullanımına uygun hatta ilgi alanına göre düşüncelerde müfessirin geçici şahsı ortaya çıkmıştır (Boas, 2013: 180.) Dövmeli bir vücuda sahip bir kadın, vücudundaki güzelliği yeniden tanımlamaktadır. Ancak ne yazık ki bu kişisel sembolizmlerin ve kişisel zevklerin geleneksel felsefedeki evrensel zevklere kıyasla çok az değeri vardır (Arp, 2012: 61). Dövme sanatçısı olan bir kişi bu tasviri şöyle tarif etmektedir: "Kelebeğin bel (omurga eğriliği) veya omuzlarının arkasına dövme yaptırılması, cinsel isteğin yüksek olduğunun ve cinsel çekiciliğin arttığının bir işaretidir. Bütün beceriyle yapmama rağmen, bu tasvirin önkol veya koldaki anlamı hakkında hiçbir şey bilmiyorum.”

Boas, fenomenlerin içsel evrimini kültürün dinamik süreçleri olarak ele elmakta ve benzer unsurların farklı kültürlerde birçok kez icat edilmiş olabileceğini kabul emektedir (Riviere, 2000: 63-64). Öyle görünüyor ki bazı durumlarda sanatçı sadece bu tasviri kullanabilmektedir ve bunu anlamanın belirli bir mantığı yoktur. Boas’a göre insan bazen anlamı açıklayamıyor ya da bilmiyor ama onu kullanabiliyor. Bazen her tasvirin tanımı ve anlamı, dövme sanatçısına tasvirin kesin bir tanımı olmayan bir dövme sanatçısı tarafindan verilmektedir.

Boas, çalışmalarında sanatçının (zanaatkarın) çizimine ancak işinde bir sorun ortaya çıktığında dikkat ettiğimizi, böylece davranışının dekoratif tasarımların kaderini daha iyi anlamamızı sağladığını işaret etmektedir. Ancak bu durumda özel sorunlar da vardır, çünkü sanatsal yaratımda rol oynayan zihinsel akımlar içsel olarak açıkça görülemez. Aslında en yüksek sanatsal üretim türleri, onları yaratan sanatçısı olmadan ortaya çıkmaktadır (Boas, 2012: 245). Ancak bazen kültürel baskılar ve bu arada malzeme eksikliği sanatçının yaratıcılığını kısıtlamaktadır. Konuya daha olumlu bir açıdan bakmak istersek belki de daha yaratıcı fikirlerin filizlenmesine ve sanatçının zihninden gelen bir yorumla yeni anlamlar üretilmesine yol açmaktadır.

\section{Kültürel ve Sosyal Yapıda Dövme}

Bedenimize dair imajımız, bedenimizi nasıl algıladığımızı, sosyal ilişkilerimizi, başkalarıyla ilişki kurma yeteneğimizi etkilemektedir (Abazari, 2008: 3). Dövme, günümüzün sosyo-kültürel yapısında karmaşık anlamlı sistemleri içeren ve bu davranış ve eylemin geçmiş bağlamında 
takibini içeren sürekli değiş̧imlerden biridir. İlkel kabileler arasında dövme için seçilen imgeler ve motifler özlü ve anlamlıydı; bu motifler bazen aile sınıfına ve bireysel onurlara atıfta bulunurdu. $\mathrm{Bu}$ örnekler günümüzde nadiren mevcuttur. Bir dövme sanatçısı, "müşteriler arasında dövme yaptıran 15 yaşında bir gençle karşılaşısım" dedi. "Vücuduna dövme yapmayı reddettim ve bunu yirmi yaş üstü insanlara yapacağımı söyledim. Genç, bir dahaki sefere babasıyla birlikte geri geldi. Babasının şimdi bir resmi işi var ve benden 15 yaşındaki oğlunun koluna onun ve babasının kolundaki dövmeyi yapmamı istedi”.

Dövme sanatçısına göre çağdaş dönemde özel aile eğilimleri olan insanlar hâlâ dövmeler için gelmektedir. Diğer bir nokta ise babanın devlet işinin, vücudundaki dövmeleri saklamasına neden olmuş olmasıdır; Yine de çocuğuna dövme yaptırmak için eşlik etmektedir. Ayrıca Sanders araştırmasında, günümüzde vücutlarına dövme yaptıran kişilerin toplumun orta, üst, varlıklı ve eğitimli kesimlerinden olduğuna ve genellikle yöneticilik ve profesyonel mesleklere sahip olduklarına işaret etmektedir (Sanderse, 1989: 153).

Dövmenin bir başka işlevi de ilkel kabilelerin insanları arasında yaygın olan sihir ve korumanın anlamıdır. Günümüzde insanlar, özellikle daha medeni topluluklarda ve gruplarda bundan kaçınmaları veya şans demeleri ve bu tasarımların kendilerine mutluluk ve servet getirdiğine inanırlar. İslam'da dövme, ilahi yaratıcıya saygısızlık olarak tanımlansa da bugün İslami İran'da çağdaş dönemde, geçmişte olduğu gibi Yemen kabilelerinin Müslümanları gibi ilkel Müslüman insanlar arasında dudaklarına ve çenelerine dövme yaptırmak yaygındı. Bu çalışmada görüşülen kişilerin çoğu İslam'i inanca sahipti. İran'ın bir İslam ülkesi olduğu düşünüldüğünde bu doğal görünmektedir. Ama mesele şu ki diğer sosyal koşulların bu insanların dini üzerindeki etkisi aşılmıştır. Bu motiflerin yeni dönemdeki işlevlerinin anlamı önceki kavimlerden farklıdır. Geçmişte bu dövmeler vücudu nazara, kısırlığa, cinsel yolla bulaşan hastalıkların tedavisine karş1 ve vücut sağlığını korumak içinken günümüzde güzelliği ve mutluluğu arttırmak dövmelerin en önemli işlevlerinden biridir (Sanderse, 145).

Ayrıca bir aktörün yaşamında edindiği etkinlikleri kullanması da bir toplumsal koşullanma sürecinin sonucudur (Lubroton, 2013: 83). Günümüzde dövme, arkadaş gruplarının etkisiyle günün saatlerini spor kulüplerinde geçiren sporcular ve gençler arasında oldukça popüler hale gelmiştir. Galsner, çağdaş toplumda büyüyen tüketim kültürüne atıfta bulunarak vücut ile fit bir vücuda sahip olmak, gençliğini korumak veya vücuduna bakmak isteyenlerin şaşırtıcı derecede artan ticari mal ve hizmet tüketimi arasındaki ilişkiyi haklı çıkarmaktadır (Abazar, 2009: 5). Çoğu 
zaman bu motiflerin vücutta yarattığı haz sosyal olarak kazanılmaktadır ve dövmeler, çağdaş toplumda tüketim kültürünün büyümesiyle mantıklı bir ilişki içinde bir sembol olarak kabul edilebilmektedir. Dövme, satanizm kültleri ve Batılı grupların hayranları ve metal şarkıcılar gibi toplumumuzda mezhepsel semboller yaratmanın yollarından biri olarak da bilinir; Sanders ayrıca dövme meraklıları için en büyük çekiciliğin belirli grupların sembolik işaretlerinden geldiğine dikkat çekmektedir. Ancak bu işaretler yeni kültürde anlamlı olmaktan uzak olabilir. Riviere (1995) de farklı kültürlerden ödünç alınan nesneler hakkında bu nesnelerin orijinal anlamlarını kaybetmiş olabileceğini söylemiştir (Riviere, 1995: 67). Bu nedenle bir kültür öğesinin bir toplumdan diğerine aktarımına her zaman bir azalma ve artış, değişim ve yeni oluşumların eşlik ettiği unutulmamalıdır.

Dövmeler hakkında toplumun kültürel yapısında erkeklerin ve kadınların dövmeler için farklı tasarımlar seçtiği söylenebilir. Sadece tasarımlar değil aynı zamanda erkeklerin ve kadınların bu iş için düşündükleri vücut bölgesi de farklıdır. Erkekler genellikle kollarına ve bacaklarına dövmeler yaparken kadınlar bu tasarımları göğüs, karın, sırt, omuz ve pelvislerinde kullanırlar. Görünen o ki bu vurgu, daha önce de değinilmiş olan kadınların süslenme yönü üzerindedir. Vücudun istenilen bölgesinin seçimindeki bu farklılıklar işlevlerindeki farklılıklara açıktır. Erkekler genellikle sosyal etkileşimlerde kimliklerini etkilemek için dövmeleri kamusal bir sembol olarak kullanırken kadınlar ise ritüel dışı bir anlayışa sahiptir. Dövmeler kadınlar için kişisel süs olarak kullanılır ve sosyal etkileşimlerinde olumlu bir nokta olmayabilir. Görüşülen kişilerden biri şuna dikkat çekmektedir: “İş yerimde vücudumda bu kalıpların varlığını kimseye söylememeliyim çünkü iş pozisyonum tehlikede. Öte yandan, bazı yüzme havuzları gibi halka açık birçok yere girmem engelleniyor ve ayrıca birçok insan bana toplumda anormal bir insan olarak bakıyor”.

Toplumdaki bu kişisel süslemeler, kişisel zevk ve çevrelerindekiler için bedenin anlamını arttırır. Kadınlar ise erkeklere göre daha çeşitli tasarımlar seçmektedir. İskeletler gibi ölüm sembollerinin karikatür görüntüleri, genellikle tribal olarak bilinen soyut motifler ve korkunç görüntüler çoğunlukla erkekler tarafından seçilir. Kadınlar belirli bir grubun üyesi değilse veya belirli bir dine mensup değilse çiçek, kelebek, efsanevi hayvanlar, tavus kuşu gibi renkli kuşlar ve yıldızın doğum ayının sembolü olan resimlerle ve gök cisimleri ve bazen kişilerin isimleri ve akrabaları ile ilgilenir. Söylenene göre bu rollerin insan vücudunda varlığına hem zevk hem de mutsuzluk eşlik etmektedir. Öte yandan vücudumuzla ilgili zihinsel imajımız kültürel bağlamlardan etkilenir ve sosyal ilişkilerimizi etkilemektedir. Böylece dövmeler kişinin imajını etkileyerek özgüven 
duygusunu, sosyal durumları ve sosyal ilişkilerin doğasını etkileyebilir. Dövmeler bazı sosyal anormalliklere rağmen insanların kültürel davranış ve eylemlerini etkileyen birçok özellik sergilemekte ve anlamlı bir sanat olarak kabul edilmektedir.

\section{Sonuç}

Dövmeler ve sanat bölümünde farklı sanat kuramlarının, ilke ve kesinlikleri sanat tanımlarına dayandırdıkları görülmüştür. Dövme, bu kuramların bazı birleşik özelliklerine sahiptir ve bu sanatsal özelliklerin bir kısmı daha belirgindir. Ayrıca düzen, simetri ve ahenk gibi en eski sanatların temel dayanağı olan estetik özelliklerden yola çıkılarak bu çalışmada gerek gerçekçi tasarımlarda gerekse geometrik ve soyut tasarımlarda düzenin zevki yansıtan ayrılmaz bir parçası olduğu görülmüştür. Resmin soyut motifleri örneğinde (b.4) şeklin tam anlamını anlamasak da izleyeni mutlu eden şey motifleri düzen ve uyum içinde oluşturmada kullanılan beceridir. Öte yandan dikey eksen etrafinda daha fazla simetri sergilenir ve yatay sıralarda daha ahenk desen tekrarları oluşturulur. Son iki durumda sanatçı ne kadar yetenekli olursa dövme tasarımları o kadar karmaşık ve güzel görünecektir.

$\mathrm{Bu}$ araştırmanın örneklerinde ve gözlemlerinde hem gerçekçi özgünlüğe sahip sanat ürünleri hem de geometrik örnekler ele alınmıştır. Gerçekçi özelliklerin gösterilmesine dayanarak üç boyutlu özelliklere sahip olması nedeniyle vücut yüzeyinde ve iki boyutta çok daha karmaşıtır. Geometrik şekillerin bazen gerçek motifleri andırdığını (Şekil a.3 ve 3.c karşılaştırması) ve sanatçının bazen konuyu ifade etmek için sadece temel nitelikleri koruduğunu belirtmekte fayda vardır. Biçimsel niteliklerdeki bu azalma, imgelerin simgesel yönünün göz ardı edilmesine atfedilemeyecek olsa da bazı durumlarda yapılan değişiklikler yeni yorumlara olanak tanımaktadır. Dikkat çeken bir diğer nokta ise tasarımların dekoratif özelliğinin düşünüldüğü durumlarda soyut, geometrik veya endüstriyel formlardan daha üstün olmasıdır. Ayrıca tasvirlerin daha kesin kültürel ve sembolik kökleri olduğu durumlarda, Faravahar'n tasviri gibi formun günümüz toplumunda işlevini yitirmesine rağmen sanatçının yaratıcılığı ana tema ile sınırlı olacaktır.

Öte yandan dövmelerin bu sanatta dışavurumcu (Expressionism) özelliğini ifade eden yönlerinden biri de dövme tasarımlarının en az durumda bu rolleri üstlenen kişi açısından onlara duygusal değer veren bir anlamı vardır. Diğerleri bu kavramlar hakkında derin bir anlayışa sahip olmasa da sadece şeklin güzelliği ile ilgili olmayan bir değerdir. Boas araştırmasında yalnızca biçim ve düşünce 
arasındaki ilişki ne kadar derin olursa sanat eserinin dışavurumcu karakterinin o kadar net olduğuna işaret etmiştir.

$\mathrm{Bu}$ araştırmanın değerlendirmelerine göre dövme tasarımlarının tanımı ve yorumlanması, o toplumun kendine özgü üslubu ve bağlamına uygun bireysel, tarihsel ve kültürel farkl1lıklara sahiptir ve bu kültürel bağ gerçekçi tasarımlarda daha belirgindir. Standart ve geometrik veya endüstriyel desenler ise daha bireysel yorumlarla gelir. Ayrıca bu sanatsal fenomende özel üslup özellikleri ve özel kültürel sınırlamalar yaratmada sosyal ve altyapı koşulları, inançlar, duygular ve sosyal faaliyetler sürekli önem ve istikrara sahiptir.

$\mathrm{Bu}$ araştırmada yapılanları özetlemek gerekirse eski çağlardan günümüze kadar insanlar arasında popüler olan bir sanat olan dövmenin, bir yandan dövme yaptırmak isteyen kişinin arzularının bir yandan sanatçının araç, teknik ve becerilerinin yan yana gelmesinin bir sonucu olduğu söylenebilir. Bu sanatın işlevlerinin sınırları eski çağlardan beri çok değişken olmasına rağmen her zaman yapılmasının bir nedeni ve tasarımlarının sembolik ve estetik düzeyde incelenebilecek bir anlamı vardır. Öte yandan çağdaş toplumumuzda ritüelist, mezhepçi, estetik ve zevk yaratma eğilimleri olan insanlar bireysel olarak veya belirli sosyal alt gruplara üyelik sonucunda bu sürekli beden değişimine yönelmişlerdir. Ancak onlar için pişmanlık olasılığı vardır ve tatmin duygusu kalıcı değildir. Bu sanatta elde edilen zevk, bu sanatı yapmak istemeyenler için bile estetik duygusu uyandırmaktan geçer ki bu da dövme sanatçısının becerisine bağlı olarak ve yeni teknolojinin yardımıyla mümkündür. Bu motifler görünüşte ilk dönemlerin motiflerine benzese de aynı anlamı taşımamış olabilir. Çünkü kültürel ve toplumsal yapı yeni anlamlar doğurmuştur. Bu nedenle dövme tasarımları ve vücutta yaratılmaları İran gibi bir toplumun kültürel ve sosyal yapısında estetik bir değer taşırken bireysel tercihler ve sosyal ilişkiler tarafindan büyütülen ve bazen de sınırlandırılan özel bir sembolik anlam ve stile sahiptir. Bu araştırmada, Franz Boas'ın yöntem ve teorilerini kullanarak güzellik kalıplarını ve ardından dövme tasarımlarının çağdaş doku ve sosyal yapı ile ilişkisini anlamsal olarak incelemeye çalıştık.

\section{Kaynakça}

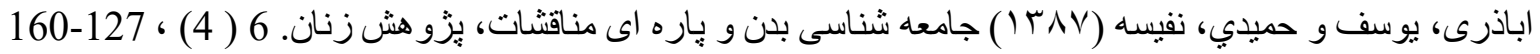

$$
\begin{aligned}
& \text { بوآس، فر انتس ( آج ا ) مردم شناسى هنر (هنر ابتدايى). ترجمه جلال الدين رفيع فر، تهران: نشر كل آذين. } \\
& \text { جل، آلفرد ( • و ا ) هنر و عامليت: به سوى نظريه جديد انسان شناختى. ترجمه احمد صبورى، تهر ان: فر هنكستان هنر. }
\end{aligned}
$$




$$
\begin{aligned}
& \text { ريوير ، كلود (TV9 ا درآمدى بر انسان شناسى. ترجمه ناصر فكو هى، تهران: نى. }
\end{aligned}
$$

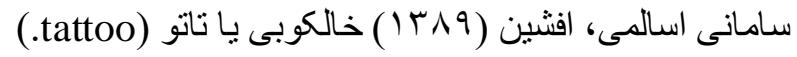

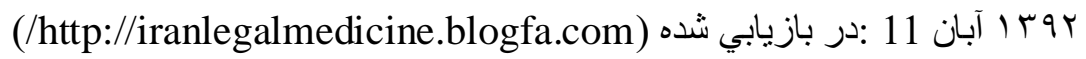

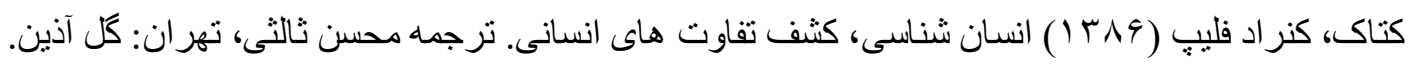

$$
\begin{aligned}
& \text { لوبرونون، داويد ( ب M I ) جامعه شناسى بدن. ترجمه ناصر فكو هى، تهران: ثالث. }
\end{aligned}
$$

Arp, R. (2012). Tattoos-Philosophy for Everyone: I Ink, Therefore I Am. UK: Wiley-blackwell.

Cuyper, C. \& Perez-Cotaps M. L. (2010). Dermatologic Complications with Body Art:

Tattoos, Piercings and Permanent Make up. London: springer. Eliade, M. (1956). The Sacred and the Profane. New York: Harvest Book.

Parry, A. (2006). Tattoo: Secrets of a Strange Art. New York: Dover Publications.

Sanders, C. R. \& Vail D. A. (1989). Customizing the Body (the Art and Culture of Tattooing).

Philadelphia: Temple University Press.

Sanders, C. R. (1991). Memorial Decoration: Women, Tattooing, and the Meanings of

Body Alteration. Michigan quarterly review, 30 (1), 146-157. 